\title{
Conceptualization of Christian Religious Attitudes in Socio-Psychological and World-View Contexts
}

\author{
Olha Palahnyuk
}

In the conditions of systemic social, and at the same time personal crisis, accompanied by values relativization, the issue of searching the ways out of this state is actualized in the scientific discourse. Overcoming the crisis depends largely on a person who is able consciously to take responsibility for the actions in the living space, which is created primarily by the personal interactions. Therefore, the social responsibility problem, its formation factors, impact on personal and psychosocial maturity has become significantly relevant in the context of social psychology and at the interdisciplinary level.

At the same time, the current socio-political situation in the country, accompanied by military conflict, complex processes of civil society development require an active social, civic, politically responsible position of citizens, especially young people that is socio-demographic group, which acts as a «barometer» of socio-economic and the political state of society and, despite the particular opportunities expansion for self-determination and individual development, it is experiencing spiritual devastation, selfishness, infantilism. The latter leads to the deformation of the youth normative and valuable sphere and require the specialists' close attention.

Thus, the aim of our study is a comprehensive theoretical and methodological analysis and conceptualization of Christian religious beliefs in sociopsychological and philosophical contexts as a factor in developing the social responsibility of the individual.

The problem of social responsibility is closely related to the development in moral and ideological spheres of personality, an important component of which is the attitude as willingness to social activity and responsibility as a result of these actions. The social attitudes analysis identifies those related to religious spirituality and Christian morality i.e. Christian religious attitudes that express personal position, conscious state of being, active buman attitude to the world in general and in particular to their self-realization. Based on a comprehensive analysis, it is determined that Christian religious attitudes in socio-psychological and worldview contexts are ideological attitudes that are the need and willingness to treat and act to people, events, 
phenomena, life, God considering the Christian morality based on faith and love to God and neighbour. In addition, they can / should be perceived as internal restraints: not freedom, but pseudo-freedom (permissiveness) and act as a natural law of conscience, the desire for the highest, the moral intuition of man.

Keywords: social responsibility of the individual, personal maturity, college students, social attitudes, worldview (life-purpose) attitudes, Christian religious attitudes, natural law of conscience.

\section{Introduction}

In the conditions of systemic social, and at the same time personal crisis, accompanied by relativization of values, in the scientific discourse the problem of searching the ways to improve this state and transformation of personal and social reality in general is actualized. To a large extent, overcoming the crisis depends on how a person is able to consciously take responsibility for his/her actions in the living space, which is created primarily by his/her personal interactions. Thus, the problem of social responsibility, factors of its formation, impact on personal and psychosocial maturity has become significantly relevant in the context of social psychology and at the interdisciplinary level, especially concerning the realization of the personal life peculiarities in a changing social space. Moreover, within each psychological scientific field there is its own vision of the acmeological features of the personality maturity expression, which provides this multi-layered and diverse phenomenon.

At the same time, the current socio-political situation in the country, accompanied by military conflict, complex processes of civil society development require an active social, civic, politically responsible position of citizens, especially young people i.e. the socio-demographic group, which acts as a «barometer» of socio-economic and the political state of society. However, today, despite the significant expansion of opportunities for selfdetermination and individual development, Ukrainian youth remains the most vulnerable and disadvantaged group of society. Despite the growing need for self-affirmation, self-determination, self-realization, the phenomenon of gradual primitivization of consciousness and selfconsciousness is often observed in modern youth. As a result, there are frequent expressions of spiritual devastation, selfishness, infantilism, which lead to the deformation of the normative and valuable spheres of young people and require specialists' close attention. 
The theoretical sources and empirical data analysis testifies to the thorough reflection of the mentioned issues in the scientific discourse. However, special practical and theoretical topicality at this stage is the research problem of the factors and models of social responsibility formation in the individual, in particular to identify ways and means of overcoming personal and social crisis. In our opinion, one of such factors of special interest is, among other things, Christian religious attitudes as the individual psychosocial regulators behaviour, significant components of the world-view in our society and the universal moral values basis. At the same time, they act both as a factor in confirming the spiritual values of civil society and as a kind of its spiritual and moral support.

The aim and objectives of the research are a comprehensive theoretical and methodological analysis and conceptualization of Christian religious beliefs in socio-psychological and ideological contexts.

\section{Theoretical basis of the research}

The Christian religious attitudes concept is considered within the research of the formation problem of individual social responsibility, which, as the analysis of scientific sources shows is an essential quality of personal maturity and is especially topical in the college student research as a sociodemographic segment. Thus, the theoretical and methodological basis of the study is the liability provision as a generalizing quality, the result of the individual integration mental functions and the subjective perception of the world M. Boryshevskyi (2010), L.M. Savchyn (2003); K.K. Muzdybayev (2010); subjective paradigm by V.O. Tatenko (2006); generalization of research on the formation of social responsibility as a property of socially mature personality (E. Fromm (2003), K. Jung (1996), W. Frankl (2001), A. Maslow (2003)); responsibility provisions as the subject stable characteristic, a stable feature; higher grade quality; closely related to the moral and ideological aspects of the individual (M. Savchyn (2003) and etc.); the concept of setting as a dynamic state by V.M. Tsvirkun (2001) position on the life meaning; dispositional concept of regulation of the individual social behavior by V.A. Yadova (1975); conceptual principles about the essence and significance of Christian religious attitudes (N. Savelyuk (2017), G. Sviderska (2016), M. Boryshevskyi (2010), O. Klymyshyn (2012), M. Karvatkovska (2011), A. Vovk (2003), L. Hrydkovets (2014)).

\section{Discussion}

In the context of considering the human world-view as a scientific problem, we should pay attention to such an important component as 
attitude. As the literature sources analysis on psychology shows, recently the attention of researchers is focused on the study of different types of attitudes in the context of the problem of individual activity and self-activity, responsibility as such an activity result. As O. Prangishvili defined, volitional responsible behaviour acts and is experienced as self-activity and selfresponsibility, namely the attitude in this case is as an indicator of «readiness for activity and responsibility» (Briñol, 2009; Palahnyuk, 2016).

The «attitude» concept is quite widely used in foreign countries (Ajzen, 2005; Briñol, 2009 and etc.) and national psychological researches (Vasyutynskyi, 2008; Kyyashko, 2010; Naydenova, 2014 and other) and is used to denote a positive or negative evaluative reaction to an object, which is expressed in cognitive evaluations (judgments), emotions and behaviour. At the same time, in the advanced scientific literature a whole synonymous series is used to define this concept i.e. attitude (Moskalenko, 2018; Palahnyuk, 2016; Sviderska, 2016), setting (Karwatkowska, 2011; Walesa, 2006) and etc. Psychological guidance in a broad sense, as noted by researchers is due to primary mental reactions, basic mental orientations and initial parental programming mechanism of the individual self-actualization in the world (Shtepa, 2007).

The study of social attitudes is devoted by modern Ukrainian (Kiyashko, 2010; Naydenova, 2014 etc.) and foreign researchers (Ajzen, 2005; Briñol, 2009). Social attitudes, as noted by L. Naydenova (2014, p. 17), contrary to the attitudes aimed at social objects; and believes that the attitude to oneself can be attributed to social attitudes, if we consider ourselves as a social object, for example, in comparison with others (which is appeared in the social self-esteem phenomenon), etc.

Researchers understand social orientation as: value orientation, internal position, social position, orientation, value and so on. In the semantic aspects of social attitudes, as noted by L. Naydenova (2014, p. 14), there are such components as axiological (values), positional (positions) and perspective (readiness, adjustment). Regarding the question of classifying social attitude to conscious or unconscious sphere, there are different/ opposite positions as some researchers refer them to the conscious, which is formed due to the internalization of social values in the process of its socialization, others consider it as an unconscious attitude to actions. We agree with the opinion by L. Naydenova (2014, p. 21) that the essence of this phenomenon is that it combines two spheres of the psyche existence into the unity, determining the focus of the subject on the diversity of different objects.

According to the research analysis, the concept of «social attitude» has different meanings; however, most authors on the structure of social 
attitudes follow the structure proposed by M. Rosenberg and K. Howland, which includes cognitive, emotional and behavioural components (Ajzen, 2005). Analysing this issue, we pay attention to the approach by V. Yadov (1975), which deals with the dispositional concept of regulation of the individual social behaviour. According to this concept, the dispositions of the individual are very close to the concept of «attitude» and a hierarchically organized system with several levels (Palahnyuk, 2016). Based on this, a separate area of the problem we study can be the identification of the manifestation levels of Christian attitudes in the system of young person dispositions.

In studying social attitudes, Ukrainian researchers talk about the possibility of using new methods (implicit, indirect methods) (Naydenova, 2014) and note that the use of modern methods on implicit measurement of social attitudes shows new possibilities for studying the process of change and reconstruction behaviour to various social objects, rethinking the accumulated experience in studying the ways of forming social attitudes.

Thus, social attitudes are seen as an interconnected treatment towards social objects, which is presented as a set of emotional, cognitive and behavioural components.

Also among the searches that study attitudes, it is worth noting a number of works devoted to the study of various social attitudes, including such as legal, authoritarian, political, consumer, religious and others. The study of legal guidelines is inextricably linked with the problems of legal awareness analysis, lawful behaviour, and socio-legal activity. The legal attitude analysis is presented in the studies of A. Vozovych (2017). Our attention is paid to A. Vozovych (2017) view, who, considering the psychological mechanisms of normative and legal regulation of individual behaviour, points out that normative and legal behaviour is normative and moral, religious and proves the absence of differences between manifestations of legal and religious attitudes by age and sex. The attitude to lawful behaviour is considered by her as a potential positive principle in an individual and more as the aim of legal education than the existing reality.

The analysis of authoritarian attitudes can be carried out in the context of the problem of authoritarian personality, which attracts the attention of representatives of philosophy, sociology, cultural studies, social and political psychology (Vasyutynskyi, 2008; Moskalenko, 2018 etc.). Foreign psychologists, studying the authoritarian personality, have defined this concept as a specific psychological type that has such features as reaction, conservatism, aggression, and thirst for power. In particular, there is interesting position of V. Moskalenko (2018) that the manifestation of the psychological characteristics of the authoritarian personality is shown in 
social stereotypes and national prejudices, as well as in politics and the education system. The attitudes of the authoritarian personality are uncritical of the existing order and stereotypes of thinking, adopted by stereotypes of propaganda, hypocrisy, in the focus on power and force.

Political attitudes and their influence on the political participation of young people were studied by the researchers' team from the Institute of Social and Political Psychology under the leadership of L. Kyyashko (2010). These guidelines are defined as the most pronounced, clearly understood type of social guidelines of the individual, which determines the methodology of bringing social reality to the human social needs norms. Political guidelines arise from the general social guidelines of the individual and determine the causes and methods of human activity (or inactivity) in order to achieve those social norms and social status, which are set by his/her social attitudes.

Consumer behaviour in society is indicated by the data of the State Statistics Committee of Ukraine, according to which the consumption level of Ukrainians is constantly growing, as evidenced by the growth rate of consumer spending from year to year, which exceeds inflation. In researches (Palahnyuk, 2015) it is identified that Ukrainian society is influenced by the ideologies of consumer and information society, which has led to the formation of consumerist attitudes among Ukrainians, and consumer activity of Ukrainians is only increasing (Moskalenko, 2018); that the development of a consumer society stimulates increasing consumer activity, and consumption is really one of the life leading aspects, the importance of which can be compared with professional activities, education, behaviour in the family circle (Karwatowska, 2011, p. 44); that the style of consumption as a whole can be defined as «stable forms of realization by the persons" consumer habits, stereotypes and values in consumer behaviour in the conditions limited by objective factors» (Palahnyuk, 2016).

Also among researches that study the attitudes, it should be highlighted those that turn to the study of religious attitudes (Savelyuk, 2017; Sviderska, 2016 etc.). The precondition of social responsibility is a choice, which is determined by the life position of the individual that is based on value imperatives, which, in particular, are related to religious spirituality to Christian morality. The spirituality concept is correlated with behaviour that is guided not by the needs but by the individual values. Spirituality is a specific and the highest form of self-regulation and self-determination of the mature person behaviour. Human actions, due to spirituality, always become an action, going beyond a certain situation.

The problem of self-actualization and self-realization in adolescence is actualized, when, according to O.S. Shtepa (2007), personal maturity is 
manifested in a sense of adulthood, readiness for independent functioning in the adult world, self-determination through reassessment of the value system. At this age, the level of mental and social maturity formation is sufficient to be the basis of a creative attitude to the world. The emergence of such ability determines the active nature of human behaviour and makes it not to depend on the circumstances, but being the master both over them, and over himself/herself.

M.M. Slyusarevskyi (2007) argues that it is the youth and the middle generation at this stage, despite the open prospect of free choice of life, had the main challenge of fate i.e. «to be or not to be». However, the expression of social tension as the society mental state, which arises in response to extreme influences, is a super-personal analogue of individual psychological states of stress, frustration, depression, aggression, which together turn into a mental state of the whole social organism and gravitate to a certain averaging and de-individualization. Agreeing with the position of V.D. Shulga (2011) on the adolescence neoplasms, we note that only with their appearance a person becomes able to «understand the social significance of their actions considering the interests and needs of another person», independently determine their way of life, their case, which indicates the presence of the latter specific action experience of social interaction and, in fact, states the intrinsic personal motivation to interact with the world similarly in the future.

V.M. Zhukovskyi (2014), analysing the role of religious spirituality in the formation of personal and spiritual maturity, concluded that to develop the right guidelines for social life, which affect the formation of man, is inconceivable without deeper insight into the spiritual sources of these, derived from the spiritual, guidelines, and therefore without experiential immersion in the Christian foundations of life and activity. O. Klymyshyn (2012), N. Savelyuk (2017), M. Karwatowska (2011), G. Sviderska (2016) point out the decisive role of religious values for the young people psychosocial maturity. However, L.M. Hrydkovets (2014) states that the Christian paradigm of personality is one of the least studied areas in psychological science, although it defines the sociality of the individual as a basic component of humanity, which serves as a projection of divine existence.

\section{The obtained results}

Analysis of the works by the in-depth psychologist-psychotherapist K.G. Jung (1996) proves that due to conscience a person is able in the process of intuitive and reflexive cognition to comprehend the inner moral 
law. Its purpose is to actualize in the psyche of the individual the significance and necessity to obey the eternal universal values, which from the beginning are preserved by its collective unconscious. Only due to this a person becomes capable of personal growth and individualization, that he/she is responsible for (Palahnyuk, 2015; Palahnyuk, 2016). According to K. Golzer, M. Honesker, Christian religious attitudes (hereinafter CRA), formed on the Ten Commandments of God, relate to the human subconscious. They come from the truth, certainly inherent to man. That is, they should not so much influence from the outside i.e. to determine, as to be internal value positions and prohibitions imposed on them.

The significant role of religion in the system of social relations, religious values and attitudes in the formation of personal maturity, in particular young people, pointed out M. Boryshevskyi (2010), L. Hrydkovets (2014), M. Karwatowska (2011), O. Klymyshyn (2012), N. Savelyuk (2017), G. Sviderska (2016), O. Yaremko (2011) and others.

Referring to the Ukrainian social environment, as M. Boryshevskyi identifies, Christian world-views are our mentality characteristics, and it is fair to say that, first, Christianity has historically been and remains the main form of Ukrainians religious world-view, and Christian values are one of the most important moral and psychological factors of formation and development of various spheres in social and spiritual life; secondly, in the Ukrainians national character, religiousness takes one of the most important places, which must be maintained as the most important of the spheres of the persons' spiritual world (M. Boryshevskyi, 2010).

Thus, the universally recognized humanistic potential of the Christian religion is mentioned in the works by N. Savelyuk (2017, p. 113), as she states that the potential is not only and not so much human as sociocentred (at least in the minds of the researched Ukrainians). In other words, the religious identity is connected to the persons' realization to his/her depersonalization, to some extent, in behalf of the large communities of the society, the world and even the universe. The author based on the results of a comprehensive study, states that the religious identity of a person is not only an aspect of his/her social identity, but also, at the same time, a counterweight to the egocentric dimensions of self-consciousness.

Analysing the religious identity of a person in the context of different levels of his/her religious activity, N. Savelyuk (2017) defines religious activity as an integrative form of human activity that periodically experiences certain sacred, not always rationally explained feelings and states (affective aspect); recognizes as true certain typical in his/her environment religious ideas and concepts (cognitive aspect); realizes and accepts religiously relevant needs, motives, intentions (motivational aspect); and also 
Trends and Prospects of the Education System and Educators' Professional ...

performs actions corresponding to all these feelings, ideas, intentions (conative aspect).

In the works of Ukrainian scientists (O. Klymyshyn (2012), G. Sviderska (2017), etc.), it is proved that faith in God is a powerful factor in preventing and overcoming the systemic spiritual crisis of youth.

Spirituality and religiosity as a problem of socio-psychological research remains relevant, because it is spirituality that is recognized as specific and one of the essential forms of self-regulation and selfdetermination of the mature person behaviour. Human actions due to spirituality always become an act, that is, is out of certain situation. Such an opportunity to go beyond the situation is given by the imagination, which allows finding psychological meaning, support in human values, and not in situational regulators (Klymyshyn, 2012; Palahnyuk, 2016).

The analysis of the relevant literature shows that religious spirituality (Christian in particular) to a greater or less extent promotes active participation in public life, without interfering in politics and authority (Boryshevskyi, 2010; Klymyshyn, 2012; Savelyuk, 2017; Sviderska, 2016).

Thus, M. Boryshevsky (2010) believes that faith in God belongs to the value orientations system, and if they are closely related to Christian morality, they motivate the individual spiritual self-improvement. As M. Savchyn (2003), the Ukrainian educator G. Skovoroda, testifies by emphasizing the individual spiritual nature of the person, pointed out that each person is endowed with a conscience i.e. the voice of God, who reminds him/her about the way and purpose of life and directs it to appropriate activities (Palahnyuk, 2016; Savelyuk, 2017).

M. Savchyn (2003) also defines that living with faith in God leads to the growth of spiritual potential, which is seen as the level of acceptance, experience and understanding by the individual «inner human» and real spiritual values (love, faith, hope).

The significant role of religiosity in taking on the role of the subject of one's own life on the basis of created meanings, positions, plans to be responsible and make meaningful life choices is discussed in G. Sviderska's (2016) research, which proves that religiosity positively correlates with responsibility, personal maturity, ability to decentralize, deep feelings and it is noted that a person's religiosity is manifested in activities and behaviour and at the same time directs the personality development.

In the analysis of religiosity S. Chernyayeva (2007) highlights such aspects as cognitive (religious knowledge and ideas, specific, mostly symbolic ways of knowing); motivational (religious needs, values, ideals, beliefs and world-view); emotional (religious experiences, which are characterized by complexity and ambivalence, a combination of opposite experiences with a 
tendency to their synthesis); activity (characterized by the coincidence of the religious actions motive with the aim of activity, which is creative, meaningful and leads to personal self-realization). Religiosity, as the researchers note, contributes to the meaningfulness of life, resists alienation, and controls personal development (Palahnyuk, 2016; Walesa, 2006) and note that the peculiarities of its manifestation are related to the religious attitudes maturity.

Thus, O. Yaremko (2011) in the context of studying the sociopsychological features of students' religiosity studied the maturity of religious attitudes (based on the «Maturity Scale by R. Yavorsky's religious attitudes») and identified two levels of their formation, which were assessed by the amount of time devoted to religious practices.

Analysis of empirical research (Hrydkovets, 2014; Lishchynska, 2008; Yaremko, 2011) shows that every second Ukrainian considers himself/herself a religious person, and among student youth $87 \%$ identified themselves as Christians. Sociological research also notes the renewal in the worldview of students of the Christian religion importance: and 32.5\% of them recognize that God exists, $38.8 \%$ of student youth consider themselves deeply religious.

At the same time, the study of religiosity and value orientations of the individual led A. Vovk (2003) to the conclusion that in the youth, in particular in the student environment to some extent lose importance moral values, Christian ideals, consumer attitudes to consumption and comfort. Such data give grounds to state that today the spiritual and cultural development of the individual is often fulfilled in a value vacuum. Public disregard for the basic norms of morality demoralizes society and, firstly, young people.

The processes that take place in our society, according to research, are accompanied by the emergence of such negative phenomena as uncertainty, value confrontation, broken ties, feelings of unhappiness and deteriorating mental health. In scientific discourse they are associated with factors of insecurity, frustration, loss, guilt, repressed aggression, self-blame, violations in the system of personal relationships, distortion of self-identity processes, impossibility of self-realization, low self-esteem, etc. (Boryshevskyy, 2010; Borets, 2017; Vasyutynskyy, 2008; Palahnyuk, 2015, Sviderska, 2016). There is a separate factor of the patterns lack i.e. ethical and cultural, professional and psychological and typological (natural diversity of psychological types of self-realization is actually often limited to one model, that is, successful, capable in competition and promotion in the Western labour market). Instead, the current socio-political situation in the country, the complex process of building civil society require an active 
social, civic, politically responsible position of citizens, especially young people

At the same time, it is important to emphasize that the social space in which the life of the individual (including modern youth) takes place is significantly expanding. Its inclusion in various social relations is intensified in the process of complicating activities, when in parallel with the growth of information consumption grows awareness of the need to make decisions with increasing risk and personal responsibility for the results of their activities, which, as defined by Borets, is one of the essential components of reflexive social competence as an integral characteristic of personality development. In this case, the growth of person's social competence, according to the author, is inextricably linked with the system of values, resolution of value conflicts and evaluation of alternatives, and its high level means that it refers to the society members; obtaines moral and ethical norms inherent in this society (Borets, 2017).

Young people, in particular the students, can be defined as a sociodemographic group, which is characterized by a fairly high level of activity, focus on finding their place in the world, the implementation of life tasks in personal and professional life, etc. (Borets, 2017; Kyyashko, 2010 etc.). This student has psychological stability and thinking lability, which is important not only for effective adaptation to the instability of today, but also for selfrealization in various spheres of life.

According to such researchers as Yu. Borets (2017) young people are the least conservative social group in terms of their value orientations; they react most sensitively to social changes, and act as a kind of «barometer» of social economic and political state of society (Borets, 2017; Klymyshyn, 2012, Moskalenko, 2018, Vasyutynskyy, 2008). It is characterized by a negative attitude to the violation of democratic norms, laws and moral principles. We can rightfully call young people, especially students, the «society social nerve» (Borets, 2017; Moskalenko, 2018; Sviderska, 2016; Vozovych, 2017).

Yu. Borets (2017, p. 42) states that student youth is able to analyse the essential aspects of the functioning and development of modern civil society, determine their own active position in it, implement moral and ethical, economic, legal, psychological principles of democracy. It is indicated that civic competence and responsibility in gaining positive experience of participation in public life, assimilation of democratic guidelines and values, cognitive mastery of political and legal culture, etc. ensure mastering the social activity and civic position.

As M. Drozdov (2016) identifies, the essence of youth and the manifestation of its main social quality is the degree of its achievement of 
social subjectivity, the degree of social relations and innovation assimilation. At the same time, it should be considered that the essential characteristics and features of such a community as youth are in a state of formation and realization, and especially for such complex entities as citizenship, civic competence, social responsibility, which should be formed, because they underlie human self-regulation and activities in society, the development of personal and social maturity. The concept of citizenship, as noted by Yu. Borets (2017, p. 49), includes an understanding of their rights and expression, the ability to use them in practice, respecting the rights and freedoms of other citizens; personal responsibility, awareness of the necessary legal and moral responsibilities, effective and critical attitude to social reality, moral beliefs, ideals of citizens' equality and the people sovereignty; ability to have a positive dialogue with the authorities, awareness of their civic identity i.e. belonging to the country, society and state.

However, nowadays, despite the significant expansion of opportunities for self-determination and individual development, Ukrainian youth has been and remains the most vulnerable, disadvantaged group of society. Despite the growing need for self-affirmation, self-determination, self-realization, the phenomenon of gradual primitivization of consciousness and self-consciousness is often observed in modern youth. As a result, the frequent manifestations of spiritual devastation, selfishness, infantilism, which lead to the deformation of the normative-value sphere of young people and require close attention of specialists. At the beginning of their own adult conscious life, professional activity or developing family relationships, the young person is faced with the task of being as creative as possible in solving related issues. Every member of this social group at this time should consciously take responsibility for their lives and treat this process as effectively and creatively as possible. It is important to say that such an attitude to the construction of the future will undoubtedly be an indicator of the psychosocial maturity of the individual and the basis of his/her creativity. And therefore, it's most important contribution to the (positive) transformation of social reality in general.

In the context of our study, the scientific investigations of O. Tsvirkun (2001) also deserve attention. He states that the world-view as a spiritually practical way of mastering the world by human and the form of his/her self-consciousness are based on stable structural components, which include those directly arising from human activity to the world. To such stable structural elements of worldview consciousness are determined the worldview attitude, worldview position of human belong worldview or semantic attitudes. The author uses this concept to record the method of 
detection, «action» of worldview and worldview consciousness, the subject of which is a person's attitude to the world. This relationship covers the entire system of the subject activities, the person who masters and creates the world of their own existence (Palahnyuk, 2016).

Thus, worldviews in their ideal sense are attitudes that are formed when a person solves worldview problems. They are subject to change when the very meaning of life changes. In this context, summarising the above, such attitudes include Christian attitudes, and therefore it is important to determine their essence with further study of the impact of Christian attitudes on the expression of the individual social responsibility.

Christian religious attitudes, formed on the Ten Commandments of God, concern the human subconscious and, as Cz. Walesa defines, they come from the truth definitely present in human. Denying the ability to know it, not wanting to notice the truth present in him/her, a person voluntarily looks away from what he does not want to see, while claiming that he is not able to know it. Therefore, even without considering oneself religious, a person knows the truth - in the form of the so-called anamnesis of its spiritual dimension. It is a remembrance of the human spirit, which is the basis of a true conscience (Walesa, 2006, p. 125-141). At the same time, in the conditions of attack on the human temptations according to the Ukrainian philosopher E. Sverstyuk (1993), there is only one protection i.e. conscience and the old props of prohibitions imposed on himself or herself (this is the essence of moral resistance of the individual and society) (Palahnyuk, 2016). We think that the key phrase for us is the phrase «prohibitions imposed on ourselves». That is, CRA (Christian religious attitudes) must be intrinsic values-safeguards set for everyone. Thus, the CRA concerns both public spirituality and, above all, religious spirituality i.e. «human-God» relationship. And the Spirit, as O. Donchenko (2011) says, is a source of inspiration for man in his/her life, including in developing relationships with others, with the world on love basis.

The analysis of socio-psychological and theological sources gave grounds to define the essence of Christian attitudes, as the «Decalogue» it is laid down in each person, as a natural law of conscience, as a desire for higher, as a moral intuition and so on. So, when a person feels the need to act/do so, and not otherwise, this is the attitudes.

It should be emphasized that in the framework of our study, the guidelines concerning the horizontal plane of Christian religiosity are taken into account (man's relationship with himself/herself and the world). Christian religious attitudes are understood by us as the need and willingness to live and act according to conscience, truth, and God's laws. In addition, they can/should be perceived as internal limiters i.e. not freedom, but 
pseudo-freedom (permissiveness). As they say: «I do so, because otherwise I cannot and do not want, because this is my position (social, life)». Violation and not following it is essentially opposite value socially oriented positions. In the religion psychology, they are understood as a conscious and voluntary transgression of the commandments (Palahnyuk, 2016). It is said of such an «act»: «He did not act in a Christian way».

\section{Conclusions and prospects for further research}

Thus, summarizing the analysis and the existing theoretical approaches to the problem of attitudes, in particular, worldview (semantic), among which in the context of the formation of social responsibility of the individual are particularly relevant Christian religious, it should be emphasized that in our understanding, $C R A$ is a world-view which is the need and willingness to relate and act in relation to people, events, phenomena, life, ourselves, God (i.e. external and internal world), etc., formed on the basis of Christian morality based on faith and love of God and neighbour.

At the same time, attitudes as readiness for social activity and responsibility, as a result of this activity, are an important component of the individual moral and ideological spheres, which are closely related to the problem of social responsibility. Christian religious attitudes, which are connected with religious spirituality, with Christian morality express a personal position, a conscious state of being, a person's active attitude to the world as a whole and his/her self-realization in it.

At the beginning of their own adult conscious life, professional activity or developing family relationships, the young person is faced with the task of being as creative as possible in solving related issues. Every member of this social group at such a moment must consciously take responsibility for their lives and treat this process as effectively and creatively as possible. It is important to note that such an attitude to the construction of the future will undoubtedly be an indicator of the individual psychosocial maturity and the basis of his/her creativity. And therefore it's most important contribution to the (positive) transformation of social reality in general. Thus, CRA in this context is the basis for the formation of selfconsistency, integrativeness, self-determination, self-construction and psychological readiness to act as the basis of personality subjectivity, its authenticity, the personal and social maturity formation.

Prospects for further research are seen in our empirical study of the Christian religious attitudes influence on the structural and semantic characteristics of personal maturity, in particular, student youth and the 
Trends and Prospects of the Education System and Educators' Professional ...

disclosure of socio-psychological potential of these attitudes in organizing psychological support at the stage of training future specialists.

\section{References}

Ajzen, I. (2005). Attitudes, Personality and Bebaviour. McGraw-Hill International. https://psicoexperimental.files.wordpress.com/2011/03/ajzeni-2005attitudes-personality-and-behaviour-2nd-ed-open-university-press.pdf

Borets, Yu. V. (2017). Social competence as an integral characteristic of personality development Theoretical and applied problems of psychology: Coll. Science. works of the East Ukrainian nat. Vladimir Dabl University. Severodonetsk, № 1(42). 29-38. http://nbuv.gov.ua/UJRN/Tippp 201716

Boryshevskyy, M. (2010). From bases of subjectivity to the tops of spirituality. Kyiv: Akademvydav Publ.

Briñol, P. (2009). Changing attitudes on implicit versus explicit measures: What is the difference? In P. Briñol, R. E. Petty, \& M. J. McCaslin. Attitudes: Insights from the New Implicit Measures. Ed. by Richard E. Petty, Russel H. Fazio, Pablo Briñol (pp. 285-326) New York, Hove: Psychology Press. https:// richardepetty. files.wordpress.com/2019/01/2009-implicit-book-ch10.pdf

Chernyaeva, S. A. (2007) Development of personality and psychological help in the light of the Christian worldview: monograph. SPb: Speech: St. Petersburg APPO.

Donchenko, O. A. (2011) From the integrity of psychological knowledge to the integrity of the worldview. Social psychology, 1 (45), 3-14. https://bvp.fmon.npu.edu.ua/images/files/Donchenko.pdf

Drozdov, O. Yu. (2016). Fundamentals of psychology of mass political consciousness: monograph. Chernihiv: Desna Poligraf.

Frankl, W. (2001) Man in search of borderline meaning. Humanistic psychology: in 3 volumes emphasis. and science. ed. R. Trach, G. Ball. K. Pulsari. 165-179.

Fromm, E. (2003). Escape from Freedom. Minsk. Harvest. http://library.khpg.org/files/docs/1456766557.pdf

Hrydkovets, L. M. (2014). Influence of family determinant on overcoming personal crises. Science and Education a New Dimension. Pedagogy and Psychology, II (10), Is. 20, 114-118.

https://seanewdim.com/uploads/3/4/5/1/34511564/hrydkovets 1 . influe nce of family generation determinant on persons ability to overcome $p$ ersonal crises.pdf

Karwatowska, M. (2011). Autorytety w opiniach mtodzoieży. Wydawca: UMCS. W. 1.

Klymyshyn, O. I. (2012). Christian-psychological foundations of the spirituality of the individual. Personality psychology. Axiopsychology of personality development in the educational environment, 1 (3), 69-78. 
Kyyashko, L. O. (2010). Influence of interaction in a team on acquisition of social maturity by the young person. Problems of political psychology and its role in becoming a citizen of the Ukrainian state: coll. Science. work, Asots. flight. psychologists of Ukraine, ISPP NAPS of Ukraine, 10, 150-161.

Lishchynska, O. A. (2008). Cult mental dependence of the individual: preconditions, factors, mechanisms. Kyiv: Legkoínk.

Maslow, A. (2003) Motivation and personality. SPb.: Peter. http://www.bimbad.ru/docs/maslow motivation and personality.pdf

Moskalenko, V. V. (2018). Features of the authoritarian personality of students of psychologists. Bulletin of VN Karazin Kharkiv National University. Series «Psychology», 64, 46-50.

https://periodicals.karazin.ua/psychology/article/view/11044

Muzdybaev, K. (2010). Psychology of responsibility. Ed. by V.E, Semenova. Moscow: LIBROCOM.

Naydonova, L. M. (2014). Group reflection as a mechanism for the reconstruction of social attitudes: dis. ... Cand. psychol. Sciences: 19.00.05 LM Naydenova NAPS of Ukraine, Inst. of Psychology named after G.S. Kostyuka. Kyiv. https://core.ac.uk/download/pdf/77241836.pdf

Palahnyuk, O. V. (2016). Psychosocial features of Christian religious attitudes in the context of the formation of social responsibility of the individual. Problems of political psychology: coll. Science. Proc., Assoc. flight. of Psychologists of Ukraine, Inst. and flight. psychology; [ed. board: L.A. Naidenova, L.G. Chorna, I.G. Batrachenko and others, 3 (17), 125-139. http://nbuv.gov.ua/UJRN/pppr 2016314

Palahnyuk, O. V. (2015). Socio-psychological factors in the formation of social responsibility of the individual: theoretical and methodological aspects. Science and Education a New Dimension. Pedagogy and Psychology, III (22), Is. 45, 96-103.

https://seanewdim.com/uploads/3/4/5/1/34511564/palahnyuk o. social and psychological factors of formation of social responsibility of perso nality theoretical and methodo- logical aspects.pdf

Religiosity of Ukrainians: level, character, attitude to certain aspects of the churchreligious situation and state-confessional relations. (2013). National security and defense. Razumkov Center, 1, 15-40. https://razumkov.org.ua/upload/Przh Religion 2013.pdf

Savchin M. V. (2003) Spiritual paradigm of psychology: monograph. K.: Akademvidav. 252 c.

Savelyuk, N. M. (2017). Basic structure of personality identity in the context of the level of its religious activity. Development and modernization of social sciences: experience of Poland and prospects of Ukraine: Collective monograph. Vol. 3. Lublin: Izdevnieciba «Baltija Publishing», 97-116. https://ir.duan.edu.ua/bitstream/123456789/695/3/colmon\%20Lublin pe d psyh Часть $\% 203$ новий-1.pdf 
Trends and Prospects of the Education System and Educators' Professional ...

Shtepa, O. S. (2007). Definition of personal maturity. Scientific studies in social and political psychology: coll. articles of the Academy of Pedagogical Sciences of Ukraine, Inst. and flight. psychology, 16 (19), 149-157.

Shulha V. (2011) Subjective-action dimension of personality education. Psychology and society: Ukrainian scientific-economic and socio-psychological journal, 2, 164-169. http://journals.uran.ua/index.php/1810-2131/article/view/121136

Slyusarevsky M. M. (2007) The social situation in Ukraine: an attempt to assess in terms of formulation and manifestation of the subjective potential of the individual. Scientific studies in social and political psychology: collection. Articles. Academy of Pedagogical Sciences of Ukraine, Inst. and flight. psychology, 16 (19), 109-127. https://ispp.org.ua/wpcontent/uploads/2019/11/Nsspp 2018 4144.pdf

Sverstyuk, Ye. O. (1993). Prodigal Sons of Ukraine. Kyiv: Knowledge.

Sviderska, H. (2016). Religiosity as an aspect of the culture of life self-determination of modern students. Formation of the culture of life self-determination of modern youth: psychological theory and practice. [Monograph] Ed. G. Radchuk. Ternopil: TNPU named after V. Hnatyuk. 450-475. https://pj.journal.kspu.edu/index.php/pj/article/view/917

Tatenko, V. (2006) Subject-action paradigm in modern psychology. Social Psychology, 1 (15), 3-13. http://nbuv.gov.ua/UJRN/Po 201515

Tsvirkun, V. M. (2001). Formation of worldviews of the person of teenage age: authors ref. dis ... cand. philos. Sciences: 09.00.04; Inst. Of Philosophy. them. G.S. Skovoroda of the National Academy of Sciences of Ukraine. Kyiv.

Vasyutynskyy, V. O. (2008). Russian-speaking community in Ukraine: threats to identity and attitudes towards integration. Scientific Bulletin of Lviv State University of Internal Affairs. Psychological series: Coll. Science. Works, ch. ed. VL Ortynsky, 1, 37-44. http://www.ispp.org.ua/backup ispp/1359549490.pdf

Vovk, A. (2003). Psychological determinants of the search for life meaning. Proceedings of the reporting scientific conference of the Faculty of Philosophy of Ivan Franko Lviv National University (pp. 175-178). Lviv.

Vozovych, A. V. (2017). Psychological features of the formation of legal awareness of college students: dis. Cand. psychol. science for special. 19.00.07 A.A. Vozovich; Kyiv. Univ. Borys Hrinchenko. Kyiv. http://elibrary.kubg.edu.ua/id/eprint/21071/1/Аисертація Возович.pdf

Walesa, Cz. (2006). Rozwój religijności człowieka. Podstawowe zagadnienia psychologii religii. Kraków: Wydawnictwo WAM. https://www.researchgate.net/profile/Jacek Prusak/publication/317036025 Religia i duchowosc w psychoterapii/links/5920ab5ba6fdcc4443f1902a/ Religia-i-duchowosc-w-psychoterapii.pdf

Yadov, V. A. (1975). On dispositional regulation of social behavior of the person. Methodological problems of social psychology: Sat. articles. resp. ed. E.M. Shorokhov (pp. 89-105). Moscow: Science. 
Yaremko, O. (2011). Personal correlates of religiosity. Social Psychology, 5 (49), 50-59.

Yunh, K. H. (1996). The structure of the psyche and the process of individuation. Moscow: Science.

Zhukovsky, V. M. (2014). Spiritual and moral knowledge of the teacher - the basis of the national revival of Ukraine in terms of modern civilizational changes. Professional pedagogical education: the formation and development of pedagogical knowledge: a monograph. (pp. 262-279). Zhytomyr: ZhSU Publishing House. I. Franko. 